\title{
Hubungan Tingkat Kecemasan dengan Tingkat Efikasi Diri pada
} Atlet Renang

Isnindri Annisa Kusumadewia*, Dhoni Akbar Ghozali ${ }^{b}$, Yunia Hastamic, Nanang Wiyono ${ }^{\mathrm{d}}$

abcdUniversitas Sebelas Maret Surakarta, Indonesia

Correspondence: isnindriannisa@student.uns.ac.id

Received: 15 Jan 2021 Accepted: 30 Apr 2021 Published: 30 Apr 2021

\begin{abstract}
Anxiety might give the tremendous impact on swimming athletes such as loss of concentration and motor ability which could result in lowering athlete's performance level in competition. Therefore, there was self efficacy as a psychological aspect which decreasing anxiety level on swimming athletes. A high self efficacy might enable athletes to face and handle the hard situations and also manage their anxiety in competition. This study aimed to determine whether there was a relationship between anxiety amd self efficacy in swimming athlete. This research was an observational study using a cross sectional approach. The subjects were 40 swimming athletes from Pyramid Swimming Club, Bogor aged 10-18 years old. The dependent variable was anxiety which measured using the Taylor Minnesota Anxiety Scale (TMAS) Questionnaire. The independent variable was self-efficacy which measured using a General Self-Efficacy (GSE) Questionnaire. Statistical analysis was performed using Product Moment Pearson test. The result showed there was correlation between anxiety and self-effcicay in swimming athletes as indicated with significance value of 0.031 and the correlation strength was low at 0.298 and the direction of correlation was negative. Based on these result it can be conclude that, there was negative correlation between anxiety and self-efficacy in swimming athletes.
\end{abstract}

Keywords: anxiety; self-efficacy; swimming athletes.

\begin{abstract}
Abstrak
Kecemasan dapat memberikan efek samping pada performa atlet renang seperti gangguan konsentrasi dan gangguan kemampuan motorik yang membuat atlet tidak dapat memberikan hasil maksimal dalam pertandingan. Guna mengatasi kecemasan perlu ditanamkan aspek psikologi yaitu efikasi diri. Atlet dengan efikasi diri tinggi percaya dirinya mampu mengatasi kecemasan yang meningkat di dalam dirinya saat pertandingan. Penelitian ini bertujuan untuk mengetahui adanya hubungan tingkat kecemasan dengan tingkat efikasi diri pada atlet renang. Jenis penelitian observasional analitik dengan pendekatan cross sectional. Subjek Penelitian 40 orang atlet renang di Pyramid Swimming Club, Bogor berusia 10-18 tahun. Variabel terikat adalah tingkat kecemasan yang diukur menggunakan kuesioner Taylor Minnesota Anxity Scale (TMAS). Variabel bebas adalah tingkat efikasi diri yang diukur dengan kuesioner General Self Efficacy (GSE). Analisis statistik yang digunakan adalah uji korelasi product moment Pearson. Hasil analisis data menunjukkan terdapat hubungan tingkat kecemasan dengan tingkat efikasi diri pada atlet renang dengan nilai signifikansi 0,031 dan kekuatan korelasi rendah sebesar 0,298 serta arah korelasi negatif. Berdasarkan hasil analisis data disimpulkan terdapat hubungan yang negatif antara tingkat kecemasan dengan tingkat efikasi diri pada atlet renang.
\end{abstract}

Kata kunci: kecemasan; efikasi diri; atlet renang. 


\section{Pendahuluan}

Kecemasan adalah kondisi psikologi yang pernah dirasakan hampir oleh seluruh orang ditandai dengan adanya perasaan khawatir, takut, dan tidak menentu (Maramis, 2010). Hal ini didukung dengan pernyataan Kaplan dan Sadock (2010) kecemasan merupakan gangguan psikiatri yang paling sering ditemukan dengan prevalensi 3-8\% per tahun. Pada atlet tingkat kecemasan akan meningkat saat menghadapi pertandingan (Husdarta 2014). Hal ini disebabkan adanya hasil yang tidak menentu sehingga atlet takut akan menghadapi kekalahan, adanya lawan yang lebih berat, serta adanya target baru yang ingin dicapai. Efek samping dari peningkatan kecemasan yang tidak terkendali adalah diare, pusing, hiperrefleks, hipertensi, palpitasi, perasaan gelisah, takikardia, kesemutan dan ekstremitas terasa dingin. Tremor, urgensi uri, kebingungan dan distorsi waktu, ruang, orang, dan situasi yang akhirnya menurunkan daya konsentrasi, daya ingat, serta asosiasi (Kaplan and Sadock 2010).

Renang adalah salah satu olahraga yang disukai oleh masyarakat Indonesia. Hal tersebut dikarenakan renang adalah olahraga aerobik sehingga bersifat ringan serta dapat memberikan banyak manfaat ketika dilakukan seperti sebagai sarana rekreasi, terapi kesehatan untuk bipokinesia, muskuloskeletal, penyakit dalam, dan masalah psikis (stres), serta bermanfaat untuk meningkatkan prestasi pada anak yang menekuni latihannya (Susanto 2015). Sayangnya, Indonesia saat ini masih belum banyak memiliki prestasi renang di pertandingan International. Sering terjadi prestasi atlet harus tertunda keberhasilannya dikarenakan kondisi psikis / mental atlet yang tidak siap untuk menghadapi pertandingan besar. Peningkatan kecemasan pada atlet renang akan memberikan efek cukup serius. Atlet renang akan mengalami peningkatan denyut nadi saat pertandingan dibandingkan saat sesi latihan sebagai efek dari peningkatan kecemasan (Blásquez, Font, and Ortís 2009). Berdasarkan penelitian yang dilakukan oleh Pratama (2018) menunjukkan peningkatan kecemasan pada atlet renang di Petrokimia Gresik dapat memengaruhi tingkat konsentrasi atlet. Selain itu efek samping dari kecemasan yang memengaruhi ekstremitas tentu akan memberi efek pada koordinasi gerakan dalam berenang.

Guna mengatasi kecemasan yang meningkat tidak terkendali maka perlu ditanamkannya aspek psikologi efikasi diri (self-efficacy). Berdasarkan teori yang diungkapkan oleh Bandura (1997) keyakinan diri seseorang akan kemampuannya untuk menyelesaikan suatu tugas atau rintangan guna menghasilkan suatu hasil yang diharapkan disebut dengan efikasi diri. Efikasi diri dapat memengaruhi kemampuan kognitif serta tindakan seseorang sehingga setiap orang memiliki tindakan yang berbeda dalam menghadapi masalah (Bandura, 2012). Efikasi diri yang tinggi pada seseorang akan membuat orang tersebut berfikir bahwa dirinya mampu memberikan solusi terhadap masalah yang dialaminya dengan membuatnya sebagai sebuah peluang kesuksesan. Atlet yang memiliki efikasi diri yang tinggi akan percaya bahwa dirinya mampu menghadapi dan mengubah suatu tekanan yang ada menjadi suatu tantangan yang siap dihadapinya. Seseorang dengan efikasi diri yang rendah akan berfikir bahwa dirinya tidak mampu memberikan suatu solusi terhadap masalah yang dihadapinya hingga akhirnya ia akan mudah menyerah.

Efikasi diri yang rendah pada seseorang akan membuat dirinya berfikir bahwa suatu masalah yang dihadapinya sebagai suatu ancaman yang memicu stres dalam pikirannya. Menurut Kaplan dan Sadock (2010) kecemasan adalah suatu bentuk respon stres yang terpicu. Maka efikasi diri yang rendah akan meningkatkan stres yang direspons sebagai sinyal yang akan menimbulkan kecemasan. Hal ini sesuai dengan penelitian sebelumnya yang dilakukan oleh Hartono (2012) dimana tingkat efikasi diri yang tinggi pada mahasiswa FK UNS dapat menurunkan tingkat kecemasan pada mahasiswa tersebut. Hal ini menunjukkan adanya hubungan erat yang berbanding terbalik antara efikasi diri dan kecemasan, dimana ketika seseorang memiliki efikasi diri yang tinggi tingkat kecemasannya yang dimilikinya akan rendah. 
Pada saat ini perhatian serta pemahaman mengenai faktor psikologis dalam pembinaan atlet untuk suatu kompetisi belum banyak diteliti. Pemahaman terhadap faktor psikologis atlet renang merupakan faktor yang penting untuk mempersiapkan atlet dalam menghadapi kompetisi selain faktor anatomi, fisiologi, dan biomekanika (Mulyana 2014).

Pyramid Swimming Club sebagai salah satu klub renang yang berada dalam jajaran elit 10 besar klub renang di Indonesia yang berlokasi di Bogor memiliki 40 orang atlet pada cabang berprestasi yang terdiri dari 20 orang atlet laki-laki serta 20 orang atlet perempuan yang berusia 10-18 tahun yang menurut kriteria WHO dan Permenkes RI No.25 tahun 2014 berada dalam kategori usia remaja. Kondisi psikologis pada setiap fase pertumbuhan akan berbeda dikarenakan pada setiap fase memiliki kondisi dan tuntutan yang berbeda. Fase remaja ini adalah peralihan dari fase anak-anak ke fase dewasa. Perkembangan psikologis pada fase remaja cenderung lebih tinggi dibandingkan dengan fase anakanak. Hal tersebut disebabkan oleh adanya tekanan sosial dan kondisi yang baru. Data dari National Comorbidity Adolescent Supplement (NCS-A) menunjukkan bahwa 31,9\% remaja berusia 13-18 tahun mengalami kecemasan.

Berdasarkan latar belakang tersebut, peneliti tertarik untuk meneliti hubungan tingkat kecemasan dengan tingkat efikasi diri pada atlet renang. Tujuan dari penelitian ini adalah untuk mengetahui adanya hubungan antara tingkat kecemasan dengan tingkat efikasi diri pada atlet renang. Hipotesis dari penelitian ini adalah terdapat hubungan antara tingkat kecemasan dengan tingkat efikasi diri pada atlet renang.

\section{Metode Penelitian}

Jenis penelitian yang digunakan dalam penelitian ini adalah penelitian observasional analitik dengan pendekatan cross sectional. Penelitian ini dilakukan di Pyramid Swimming Club Bogor pada minggu keempat bulan September tahun 2020 melalui pengisian google form. Populasi penelitian ini adalah atlet renang di Pyramid Swimming Club dengan kriteria restriksi : berusia 10-18 tahun, mengikuti klub renang minimal 6 bulan, bersedia mengikuti penelitian dengan mengisi informed consent, mengisi dan mengirimkan kuesioner, tidak mengalami kondisi gangguan kejiwaan, tidak dalam kondisi yang menyebabkan kecemasan meningkat seperti adanya permasalahan keluarga, kematian/ kecelakaan keluarga dekat, serta tidak mengonsumsi obat-obatan antianxiety.

Sampel penelitian ini berjumlah 40 orang atlet. Teknik sampling yang digunakan dalam menentukan sampel adalah total sampling, dimana jumlah sampel sama dengan jumlah dari populasi. Besar sampel menggunakan Rule of Thumb dimana data penelitian yang dianalisis memiliki sampel berjumlah minimal 30 sampel. Variabel bebas dalam penelitian ini adalah tingkat efikasi diri, sedangkan variabel terikatnya adalab tingkat kecemasan pada atlet renang. Pengambilan data dilakukan dengan menggunakan kuesioner Taylor Minnesota Anxiety Scale (TMAS) untuk mengukur tingkat kecemasan dan kuesioner General Self Efficacy (GSE) untuk mengukur tingkat efikasi diri. Teknik analisis data dilakukan menggunakan uji korelasi product moment pearson.

\section{Hasil}

Penelitian ini dilakukan pada minggu ke empat bulan September 2020 dengan subjek penelitian 40 atlet renang di Pyramid Swimming Club Bogor berusia 10-17 tahun yang terdiri dari 20 subjek lakilaki dan 20 subjek perempuan. Hasil dari penelitian didapatkan nilai dan frekuensi dari Taylor Minnesota Anxiety Scale (TMAS) dan General Self Efficacy (GSE) sesuai pada gambar 1. 


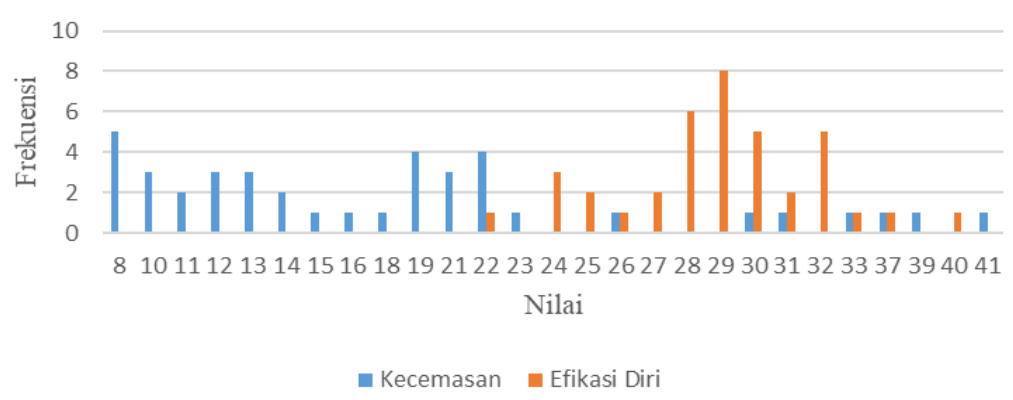

\section{Gambar 1. Grafik Frekuensi Nilai Kecemasan dan Nilai Efikasi Diri Atlet Renang}

Berdasarkan Gambar 1 dan pembagian 3 interval kelas dari rentang nilai kuesioner TMAS maka tingkat kecemasan pada atlet renang dapat dikategorikan menjadi tinggi, sedang, dan rendah dengan perhitungan berikut :

Kategori rendah : Nilai Minimum $\leq \mathrm{x}<\mathrm{Q} 1=0 \leq \mathrm{x}<16,67$

Kategori sedang: Q1 $\leq \mathrm{x}<\mathrm{Q} 2=16,67 \leq \mathrm{x}<33,34$

Kategori tinggi : $\mathrm{x} \geq \mathrm{Q} 2=\mathrm{x} \geq 33,34$

Dari pengkategorian tersebut didapatkan 20 orang atlet mengalami tingkat kecemasan rendah, 17 orang mengalami tingkat kecemasan sedang dan 3 orang mengalami tingkat kecemasan tinggi.

Berdasarkan Gambar 1 dan pembagian interval 3 kelas dari rentang nilai kuesioner GSE maka tingkat efikasi diri pada atlet renang dapat dikategorikan menjadi tinggi, sedang, dan rendah dengan perhitungan berikut :

Kategori rendah : Nilai Minimum $\leq \mathrm{x}<\mathrm{Q} 1=10 \leq \mathrm{x}<20$

Kategori sedang: Q1 $\leq \mathrm{x}<\mathrm{Q} 2=20 \leq \mathrm{x}<30$

Kategori tinggi : $\mathrm{x} \geq \mathrm{Q} 2=\mathrm{x} \geq 30$

Dari pengkategorian ini didapatkan 23 orang atlet memiliki tingkat efikasi diri sedang dan 17 orang atlet memiliki tingkat efikasi diri yang tinggi.

Tabel 1. Hasil uji normalitas data

\begin{tabular}{cc}
\hline Variabel & Shapiro-wilk $(p)$ \\
\hline Efikasi Diri & 0,085 \\
Kecemasan & 0,056 \\
\hline
\end{tabular}

Berdasarkan hasil uji normalitas data dengan Shapiro-wilk didapatkan nilai $\mathrm{p}$ dari variabel efikasi diri $0,085>0,05$ dan variabel kecemasan 0,056 > 0,05 yang menunjukkan distribusi dari kedua variabel tersebut terdistribusi normal. 


\section{Tabel 2. Uji Linieritas}

\begin{tabular}{llllll}
\hline & & df & F-hit & F-tab & Sig \\
\hline \multirow{2}{*}{ Kecemasan* Efikasi Diri } & $\begin{array}{l}\text { Deviation from Linearity } \\
\text { Within Groups }\end{array}$ & 13 & 0,982 & 2,14 & 0,540 \\
& & 25 & & &
\end{tabular}

Dari Tabel 2. didapatkan hasil uji linieritas nilai Sig. Linieritas sebesar 0,540 >0,05 dan nilai F diperoleh sebesar 0,982 < Ftabel 2,14, maka didapatkan hubungan linear secara signifikan antara variabel bebas tingkat efikasi diri dengan variabel tingkat kecemasan.

Tabel 3. Uji korelasi

\begin{tabular}{llll}
\hline & & Efikasi Diri & Kecemasan \\
\hline \multirow{3}{*}{ Efikasi Diri } & Pearson Correlation & 1 &,- 298 \\
& Sig. (1-tailed) & &, 031 \\
& N & 40 & 40 \\
\multirow{2}{*}{ Kecemasan } & Pearson Correlation & $-2,98$ & 1 \\
& Sig. (1-tailed) & 0,031 & \\
& N & 40 & 40 \\
\hline
\end{tabular}

Berdasarkan tabel 3 didapatkan hasil uji korelasi product moment pearson dengan nilai signifikansi variabel sebesar $0,031<0,05$ yang menunjukkan bahwa adanya korelasi / hubungan yang signifikan antara variabel efikasi diri dengan kecemasan pada atlet. Nilai korelasi didapatkan sebesar $\mathrm{P}=-0,298$ dapat diartikan bahwa hubungan antar variabel bermakna tetapi memiliki korelasi yang rendah. Tanda negatif menunjukkan bahwa kedua variabel memiliki hubungan yang negatif, semakin tinggi tingkat efikasi diri maka tingkat kecemasan semakin rendah.

\section{Pembahasan}

Pada data hasil penelitian dapat diketahui jumlah sampel sebanyak 40 orang dengan jumlah responden laki-laki sebanyak 20 orang $(50 \%)$ dan responden perempuan sebanyak 20 orang (50\%). Dari hasil penelitian didapatkan bahwa pada atlet berjenis kelamin laki-laki memiliki nilai kecemasan yang lebih rendah dibandingkan dengan atlet perempuan. Kecemasan paling sering terjadi pada perempuan, dikarenakan perempuan lebih mudah terpengaruh oleh tekanan-tekanan yang menimbulkan stresor sehingga kondisi psikisnya menjadi lebih sensitif dan emosional. Adanya fluktuasi dari kadar estrogen dan progesteron pada perempuan juga menjadi penyebab timbulnya masalah kecemasan pada perempuan menjadi lebih tinggi dibandingkan laki-laki (Woldegerima et al. 2018).

Rentang usia dari 40 orang sampel atlet adalah 10 - 17 tahun, berdasarkan kriteria dari WHO dan Kemenkes usia ini berada di rentang usia remaja yaitu 10 - 18 tahun. Menurut Supriyantini (2010) faktor individu yaitu usia dapat memengaruhi kondisi psikis. Bertambahnya usia seseorang maka tingkat efikasi diri akan semakin meningkat, ia akan semakin merasa dirinya mampu menangani keadaan yang dihadapinya menjadi lebih baik.

Dari hasil penelitian didapatkan bahwa 20 orang atlet mengalami tingkat kecemasan rendah, 17 atlet mengalami tingkat kecemasan sedang, dan 3 orang mengalami tingkat kecemasan tinggi. Perbedaan tingkatan kecemasan tersebut dapat dikarenakan adanya berbagai faktor internal dan faktor eksternal yang memengaruhi atlet. Faktor internal yang dapat memengaruhi seperti genetik, moral, pengalaman bertanding, perasaan takut dimarahi / dicemooh, dan pemikiran puas diri yang berlebihan dimiliki oleh atlet renang tersebut. Sedangkan untuk faktor eksternal yang dapat memengaruhi tingkat kecemasan seorang atlet renang adalah peranan keluarga, peranan pelatih, penonton, lawan tanding yang dihadapi, serta tingkat pertandingan yang dihadapinya (Gunarsa 2014). Dalam penelitian ini atlet yang 
mengalami tingkat kecemasan tinggi sangat sedikit, hal ini dikarenakan pengambilan data dilakukan pada saat atlet dalam kondisi latihan rutin bukan saat atlet akan menghadapi pertandingan, sehingga stresor yang dialami oleh atlet rendah. Guna mencegah peningkatan kecemasan saat akan menghadapi pertandingan pada atlet terutama yang sudah berada di tingkat kecemasan sedang dan tinggi dalam saat latihan rutin terdapat beberapa cara untuk menurunkan tingkat kecemasan pada atlet yaitu dengan melakukan olah teknik pernapasan, self talk, fokus pada pertandingan, dan bisa berkonsultasi pada pelatih mengenai kecemasan yang dihadapinya (Gilas 2018). Pelatih memiliki peranan penting dalam mengelola kecemasan seorang atlet mulai dari saat pelatihan hingga dalam menghadapi kompetisi.

Dari hasil pengkategorian didapatkan 23 atlet memiliki tingkat efikasi diri yang sedang dan 17 orang atlet memiliki tingkat efikasi diri yang tinggi. Hal ini menunjukkan bahwa semua atlet dalam penelitian ini sudah memiliki nilai efikasi diri yang baik, yang dapat memberikan pengaruh terhadap keyakinan diri yang dimilikinya. Menurut Bandura (2012) ada beberapa faktor yang memengaruhi tingkat efikasi diri setiap individu yaitu pengalaman keberhasilan, pengalaman orang lain, persuasi verbal, serta kondisi fisiologi tubuh. Dengan banyaknya pengalaman keberhasilan dari atlet dalam pertandingan, adanya dukungan dari orang-orang disekitarnya dalam kariernya sebagai atlet, serta kondisi fisiologi tubuh yang baik membuat tingkat efikasi diri yang tumbuh pada atlet renang dapat meningkat.

Tabel 3 menunjukkan nilai signifikansi (p) antara variabel kecemasan dengan efikasi diri sebesar 0,031 $<0,05$ yang menunjukkan bahwa Ho ditolak pada $\mathrm{p}<0,05$ (Priyatno 2011). Hal ini menunjukkan bahwa hipotesis terdapat hubungan antara tingkat kecemasan dengan tingkat efikasi diri pada atlet renang dalam penelitian ini dapat diterima. Hasil penelitian ini sesuai dengan penelitian sebelumnya yang dilakukan oleh Amila (2019) bahwa terdapat hubungan yang signifikan antara variabel efikasi diri dengan variabel kecemasan. Pada tabel 3 uji korelasi didapatkan nilai korelasi product moment pearson yang negatif sebesar $-0,298$. Hal ini menunjukkan bahwa adanya korelasi linear negatif antara variabel tingkat kecemasan dengan tingkat efikasi diri pada atlet renang, dimana semakin tinggi tingkat kecemasan seorang atlet renang maka akan semakin rendah tingkat efikasi diri atlet tersebut, begitupun sebaliknya. Seseorang yang memiliki efikasi diri yang tinggi ia akan memengaruhi kemampuan kognitif yang dimilikinya. Kemampuan kognitif salah satunya terdiri dari keyakinan diri yang akan ikut meningkat ketika kemampuan kognitif meningkat. Keyakinan diri adalah salah satu faktor yang dapat memengaruhi tingkat kecemasan. Maka seseorang yang memiliki tingkat efikasi diri yang tinggi dapat membuat dirinya berusaha untuk mengendalikan tingkat kecemasan dalam dirinya dan fokus dalam mencapai target yang ingin dicapainya. Hasil penelitian ini sesuai dengan penelitian sebelumnya yang dilakukan oleh Putri, dkk. (2017) dimana didapatkan hubungan yang berbanding terbalik antara efikasi diri dengan tingkat kecemasan pada siswa yang akan menghadapi ujian nasional. Hal ini juga pernah diungkapkan oleh Bandura (2007) bahwa tingkat efikasi diri akan memberikan pengaruh dalam penurunan tingkat kecemasan. Walaupun penelitian ini memiliki arah korelasi yang berbanding terbalik dan memiliki nilai korelasi yang bermakna tetapi nilai korelasi hanya sebesar 0,298 yang menurut kriteria dari Colton \& Sarwono (2018) nilai di antara 0,21 -0,40 memiliki korelasi rendah. Korelasi yang rendah menunjukkan bahwa adanya pengaruh faktor-faktor internal dan eksternal lainnya pada atlet renang di Pyramid Swimming Club yang memengaruhi besarnya hubungan antara tingkat efikasi diri dengan tingkat kecemasan. Berbeda dengan penelitian yang dilakukan oleh Hartono (2012) didapatkan bahwa nilai korelasi yang tinggi sebesar 0,684 antara pengaruh efikasi diri dengan tingkat kecemasan pada mahasiswa FK UNS yang menunjukkan bahwa hubungan antara kedua variabel tersebut lebih kuat dibandingkan faktor eksternal dan faktor internal lainnya. Hal ini dapat dikarenakan penelitian dilakukan pada saat atlet melakukan latihan rutin saja bukan pada saat akan menghadapi pertandingan, sehingga kurang adanya tekanan yang dapat memengaruhi kondisi psikologis atlet.

Penelitian ini telah dilakukan berdasarkan prosedur ilmiah, namun masih ada keterbatasan dalam penelitian ini, yaitu penelitian ini dilakukan bukan pada saat atlet menghadapi pertandingan melainkan hanya pada saat atlet melakukan latihan rutin sehingga kurang adanya tekanan yang dapat memengaruhi kondisi psikologis atlet. Penelitian ini juga dilakukan secara daring menggunakan 
google form dengan jumlah item pertanyaan kuesioner yang cukup banyak sehingga membuat kemungkinan responden memberikan jawaban di pertanyaan - pertanyaan bagian akhir menjadi tidak sungguh - sungguh yang akan memengaruhi hasil akhirnya. Pada penelitian ini jumlah sampel juga masih sangat kecil sehingga penelitian belum bisa digeneralisasikan.

\section{Simpulan dan Rekomendasi}

Berdasarkan hasil penelitian yang dilakukan menunjukkan bahwa terdapat hubungan negatif antara tingkat kecemasan dengan tingkat efikasi diri pada atlet renang. Disarankan kepada atlet renang sebaiknya dapat mengendalikan tingkat kecemasan yang dirasakannya dengan meningkatkan efikasi diri sehingga dapat meningkatkan prestasi dalam olahraga renang. Kepada pihak pelatih dan pembina disarankan dapat lebih memerhatikan kondisi psikologis dari para atlet dalam pembinaan persiapan kompetisi dengan memberi dukungan positif sehingga dapat menurunkan tingkat kecemasan dan meningkatkan efikasi diri dari atlet tersebut. Kepada peneliti selanjutnya perlu dilakukannya penelitian lebih lanjut dengan subjek lain, jumlah sampel yang lebih besar, populasi yang lebih luas, serta menganalisis variabel perancu lain sehingga dapat memberikan hasil yang lebih akurat dan memperkecil bias.

\section{Daftar Pustaka:}

Amila, Ayuning Mutthia. 2019. "Hubungan Efikasi Diri Dengan Kecemasan Pada Pasien Pre Operasi Di Rumah Sakit Tingkat III Baladhika Husada Jember.” Universitas Jember.

Bandura, A. 1997. "Self-Efficacy: The Exercise Of Control.” New York: W.H.Freeman.

Bandura, Albert. 2007. “Self-Efficacy Conception of Anxiety. Anxiety Research.” 1(2):77-98.

Bandura, Albert. 2012. "On the Functional Properties of Perceived Self-Efficacy Revisited.” Journal of Management 38(1):9-44. doi: 10.1177/0149206311410606.

Blásquez, Julio César Cervantes, Gil Rodas Font, and Lluís Capdevila Ortís. 2009. "Heart-Rate Variability and Precompetitive Anxiety in Swimmers." Psichotema 27(4):6.

Colton, and Sarwono. 2018. Buku Metode Penelitian KuantitatifDan Kualitatif. 2nd ed. Yogya: Graha Ilmu.

Gilas, L. 2018. “Tingkat Kecemasan Ditinjau Dari Jenis Kelamin Dan Jenis Olahraga Pada Atlet Unit Kegiatan Mahasiswa (UKM) Unit Olahraga Di Universitas Islam Negeri Maulana Malik Ibrahim Malang." Universitas Islam Negeri Maulana Malik Ibrahim Malang.

Gunarsa, Y. 2014. Psikologi Olahraga Prestasi. Jakarta: BPK Gunung Mulia.

Hartono, Dwi Rachmawati. 2012. "PENGARUH SELF-EFFICACY (EFIKASI DIRI) TERHADAP TINGKAT KECEMASAN MAHASISWA FAKULTAS KEDOKTERAN UNIVERSITAS SEBELAS MARET SKRIPSI.” Universitas Sebelas Maret.

Husdarta, H. J. S. 2014. Psikologi Olahraga. 3rd ed. Bandung: Penerbit Alfa Beta.

Kaplan, and Sadock. 2010. Buku Ajar Psikiatri Klinis. 2nd ed. Jakarta: Penerbit Buku Kedokteran EGC.

Maramis, W., and A. Maramis. 2010. Catatan Ilmu Kedokteran Jiwa. 2nd ed. Surabaya: Airlangga University Press.

Mulyana, Boyke. 2014. "HUBUNGAN KONSEP DIRI, KOMITMEN, DAN MOTIVASI BERPRESTASI DENGAN PRESTASI RENANG GAYA BEBAS.” Jurnal Cakrawala Pendidikan 3(3). doi: 10.21831/cp.v3i3.1636.

Pratama, Bella. 2018. "Pengaruh Kecemasan Terhadap Konsentrasi Pada Atlet Renang Petrokimia Gresik." JOSS AE: Journal of Sport Science and Education 3(2):76. doi: 10.26740/jossae.v3n2.p7680. 
Priyatno, D. 2011. Buku Saku Analisis Statistik Data SPSS. Yogyakarta: Mediakom.

Putri, Sikka Widyaning, Rini Risnawita Suminta, and Diah Handayani. 2017. "HUBUNGAN EFIKASI DIRI DENGAN KECEMASAN MENGHADAPI UJIAN NASIONAL PADA SISWA.” Happiness Journal of Physiology and Islamic Science 1(2):14.

Supriyantini, S. 2010. "Perbedaan Kecemasan Dalam Menghadapai Ujian Antara Siswa Program Reguler Dengan Siswa Program Akselerasi." Universitas Sumatera Utara.

Susanto, Ermawan. 2015. "MANFAAT OLAHRAGA RENANG BAGI LANJUT USIA." MEDIKORA (1). doi: 10.21831/medikora.v0i1.4669.

Woldegerima, Y., G. Fitwi, H. Yimer, and A. Hailekiros. 2018. "Prevalence and Factors Associated with Preoperative Anxiety among Elective Surgical Patients at University of Gondar Hospital. Gondar, Northwest Ethiopia, 2017. A Cross-Sectional Study.” International Journal of Surgery Open 10:21-29. 